An overlooked role for faculty members in advancing teaching and learning is that of the research advisor who teams with students interested in faculty careers.

\title{
Advancing STEM Teaching and Learning with Research Teams
}

\author{
Brian P. Coppola
}

One of the driving editorial questions for this volume is disconcerting: "Why should faculty members work to enhance undergraduate education?" This is partly because I have an idiosyncratic view on the topic, having built my academic career on an interdisciplinary combination of chemistry and education (Huber, 2004). But mostly the reason is that the answer seems so simple: "It's our job; we are the professors ... the keepers of the flame of education. ... If we do not do this, the flame goes out." A more complicated answer is also valid: "Professors have a great deal to do, and our lives are filled with conflicting priorities, increasing demands; one person cannot do everything." Consequently, some familiar solutions to enhancing undergraduate education include outsourcing (hiring some nontenure-track educationalists to take care of this, or even when tenured, at a reduced status), remedial education (consultation with the members of the professional development community who staff the teaching centers), and various forms of denial or bravado ("not my job," "I have important experiments to conduct," "students are just not the same as in the olden days ..."). And yet in my experience, departments are usually made up of well-intentioned faculty colleagues who sincerely want to do a great job in their classroom teaching, but lack exactly the thing that made them terrific researchers: adequate preparation for the responsibilities of being an independent and creative practitioner. 
In this chapter, I begin with something that is nearly self-evident: a primary reason that STEM faculty members are so successful in research, even in the face of constantly changing and exponentially growing information, is the highly intentional program of professional preparation that they receive. For over a hundred years, professional preparation has catapulted individuals who are barely ten to twelve years out of high school to the leading edges of their discipline and provides the sort of readiness that makes them independent and creative practitioners. They are ready to take on and invent new solutions to complex, challenging problems.

The critical component that allows STEM researchers to continue to carry out research even when demands grow and life complicates is the research group: the quid pro quo trade we make to educate the next generation in exchange for getting students to work on our research ideas. Because teaching and learning are areas that intersect every discipline in academia and represent the special dual nature of being a professor (to advance understanding and how we educate), I argue that understanding our system of professional preparation for STEM research is perhaps the best model for how to prepare the future members of the professoriat, but is also exactly what today's professors need in order to get involved with improving undergraduate education.

\section{Preparing the Next Generation for Research}

I am compelled by the idea that the most unique and important thing we do, as academic scientists, is identify, nurture, and ultimately move the next generation past what we could accomplish. Our system of scholarly development in research is built on using research as a vehicle for educating students to be the next generation of scholars.

The concept of inherited wisdom is particularly keen in the STEM disciplines because research groups are the norm. As a consequence, ironically enough, the senior member of an academic scientific research team (the faculty advisor) is generally identifiable as the person who does not personally carry out experiments. And if you remove the research students from any science department, it is fair to say that the amount of new knowledge produced would damp to zero in short order. Although it is also fair to say that scientists and engineers have taken the most strategic advantage of the research group, a faculty member such as my colleague Eric Rabkin, a professor of English, has adapted the research group model to take on a problem in analyzing short stories (Genre Evolution Project at the University of Michigan, 2007a).

Roald Hoffmann (private communication, October 2003) believes that research groups, as we know them, are the primary reason that graduate students in the United States hopscotch in creative ability over their bettertrained European and Asian counterparts during graduate school. Is this true? We do not know. As a mid-twentieth-century phenomenon, large academic research groups have been studied as organizational structures by only a few educational researchers (Lave and Wenger, 1991; Latour, 1987; 
Latour and Woolgar, 1991; Goodwin, 1995; Newstetter, 2005). Much more work is needed to understand research groups, because they are an important mechanism by which the intellectual and social "genes" for learning about scholarship (what Dawkins, 1989, calls memes) are inherited.

Research groups are the nuclear families of academia, and the obligation we have to replace ourselves in academia is profound. If academic scientists stopped doing research, discoveries would still be made. If academic scientists stopped filing patents, inventions would still be invented. But if academic scientists stopped educating the next generation of academics, the entire system of educating scientists comes to a swift and grinding halt.

We owe it to the next generation to educate as well as possible, and my thesis is that integrating a scholarly development model in teaching and learning-for all of those who become the next generation of academics, based on what we know from research-is the necessary next step in the evolution of our profession.

\section{Preparation for Teaching}

In arguing for a "broader, more capacious meaning" of scholarship (Boyer, 1990; Glassick, Huber, and Maeroff, 1997), Boyer and his colleagues proposed that in addition to a scholarship of discovery (that is, the tenets of scholarship as applied to research), there could be a scholarship of teaching and learning (SoTL). The SoTL community comprises a widespread group of faculty members, administrators, and personnel from college and university teaching centers (Indiana University, 2007).

Randy Bass, in a seminal 1999 article, provides what I think is a powerful litmus test for the existence proof of a scholarship of teaching and learning. One telling measure of how differently teaching is regarded from traditional scholarship or research within the academy is what a difference it makes to have a "problem" in one versus the other. In scholarship and research, having a "problem" is at the heart of the investigative process; it is the compound of the generative questions around which all creative and productive activity revolves. But in one's teaching, a "problem" is something you don't want to have, and if you have one, you probably want to fix it. Asking a colleague about a problem in his or her research is an invitation; asking about a problem in one's teaching would probably seem like an accusation.

In other words, we readily differentiate between the meaning of the word problem in the following two phrases: "my research problem" and "a problem with my research." In the first case, we mean a project in which we are investing our scholarly energy, into which we welcome students and faculty collaborators in an intellectual pursuit. In the second case, the sense of the word problem shifts to a difficulty that needs to be fixed. When you quite literally swap the word teaching for the word research in those phrases, the dual meaning of the word problem disappears. We read and understand "my teaching problem" as synonymous with "a problem with my teaching." 
Language is revealing. A scholarship of teaching and learning will not exist, I believe, until we have language (and therefore the idea) that differentiates the meaning of the two "teaching" phrases to the same degree that we differentiate the two "research" phrases.

If the meaning of scholarship is broad and capacious, then, as a first approximation, the "teaching" for "research" swap can be used to help clarify what a scholarship of teaching and learning looks like. By studying and describing the characteristics of scholarship that we understand so well from research, we can then quite literally read how the tenets of scholarship suggest what is needed to advance teaching and learning. In the following statements, which were originally a set of four characteristics of scholarship in research (Coppola, 2007), I have used the "Bass substitution strategy" to generate statements for the characteristics of scholarship in teaching and learning:

- Scholarship in teaching and learning means that the work is informed. A teacher should know as much as is knowable about the problem, how to search that information out, how the problem fits into the overall needs and interests of the teaching community, and how to evaluate the scope and limitations of the teaching methods that were used to generate the resulting knowledge. A teacher understands the standards of practice that affect the design of a project, including critical issues of intellectual property, authorship, ethical conduct, and resolution of conflicts.

- Scholarship in teaching and learning means that the work is intentional. A teacher should be able to link explicitly, or align, the informed goals of a project with the methods being used to implement it, and to have defensible arguments for why these choices will result in the expected knowledge gains. A teacher should provide multiple and reliable sources of evaluation data that address directly the goals set out by the teaching objectives and the methods used to implement the teaching design.

- Scholarship in teaching and learning means understanding that the model is impermanent. Teachers understand that their contributions are tentative and theory laden, and the new questions that arise from their teaching will make the work itself a target for falsification. The decreasing halflife of information has significant consequences for the lives of academic teachers, or, said more plainly, it is not so much that we are eliminating the flat earth model as much as we are creating the next best version of it. Only intellectual arrogance makes us think that we have finally found a single, immutable answer to anything. The phenomena (motivation, cognition, creativity, and so forth) remain, but at any moment, the model is open to evolution or revolution. Understanding impermanence can keep teachers critical about their own work and less inclined toward conservative critics who say, "Science teaching progresses funeral by funeral."

- Scholarship in teaching and learning means that both results and processes are inheritable. Teachers provide the kind of documentation of their work 
that allows other teachers to evaluate it without having looked over the shoulder of the practitioner. A teacher's body of work exists in forms that can be shared, learned from, and built on. However, there is much more to the process of becoming a teacher who follows the tenets of scholarship than having access to a good library. All of the characteristics of scholarship ... work that is informed, intentional, and documented and acknowledges impermanence ... need to be learned, too. And as with most things, explicit and deliberate instruction is better than implicit and haphazard instruction.

\section{Building Teaching Groups on the Experience of Building Research Groups}

Faculty members in the laboratory sciences currently develop their teaching ideas quite differently than they do their research ideas. In fact, they carry out teaching projects the same way a historian does research: alone. Yet particularly in science, we successfully involve inexperienced students in our discovery research plans, using a system that engages potential researchers as early as their entry into college, and one that continues to move them along through the end of their postdoctoral period. That same system should, hypothetically, engage those students who want to add education, along with science, to their professional preparation-not all students but rather that subset interested in academic careers.

Working on large, team-based projects is not a priori limited to scientific research just because science caught that particular wave when the tide of public funding came in. As a strategy to improve professional readiness for future faculty members, building teaching groups from the personnel in our research groups, and taking on the teaching missions of our departments, serves everyone. As academics, attending to the best possible professional readiness for those who become professors is our unique and key obligation; our only choice is how well (or badly) we do it.

To enhance undergraduate education, we need to combine faculty members, and their big ideas about research and teaching, with the students who want to add this combination to their education: the future faculty. In my department, building teaching groups started by following the Bass substitution strategy: the things we do to promote professional readiness for research already exist (Coppola and Roush, 2004; Coppola, 2007). Over the past ten years, if the question was, "How do we handle this for doing teaching projects?" then we have learned that the first, best answer is, "Let's take a look at what we already do in research and create an analogy." In the abstract, this means:

1. Thinking about instructional design that will not only identify students for their potential as researchers, but also for their potential as teachers 
2. Thinking more expansively about what you ask students to do in a course because you are going to partner with your instructors-intraining on your teaching ideas in the same way you partner with your researchers-in-training on your research ideas

3. Thinking through what parts of a project can be implemented by undergraduate collaborators, graduate collaborators, and postdoctoral collaborators

4. Working with people outside your areas of expertise in order to innovate with instructional design or to collect and understand assessment data

5. Providing course work and seminars for students in areas of education

6. Finding fellowship support for Ph.D. students and postdoctoral associates, because that is how we operate in general when we carry out interdisciplinary work

7. Embracing that all of the participants are still first and foremost (in my department) chemists, and not a separate or segregated subset of faculty members and students who are the educationalists, but rather that subset of mainstream scientists in the department who want to add this work to their portfolio

8. Having, in the first iteration, one or two faculty members who can take leadership for organizing and administering this activity within the department

A decade later, we have made progress. When my colleagues think about doing instructional development, they think about partnering with students in order to get that work done (Gottfried and others, 2007). We have sections of our first-year courses where the instruction is deliberately designed to help reveal both disciplinary expertise and the ability to teach along with creating instructional materials (Hayward and Coppola, 2005; Varma-Nelson and Coppola, 2005). Our colleagues in the University of Michigan School of Education have adapted some of their graduate courses so that postsecondary education is featured along with precollege science education, and our graduate students take these courses. We have used funding from the U.S. Department of Education's GAANN program (Graduate Assistantships in Areas of National Need) to support graduate students (as one might with a training grant) who wanted to add significant work in education to their chemistry Ph.D. program, and a number of these students have included chapters on their scholarship of teaching and learning in their written theses. In fall 2007, we had eight postdoctoral associates in the department whose primary residency was in one of the department's research groups, into which they had been recruited, but who also held a mentored teaching assignment as an instructor in one of our coursesgenerally, but not always, as part of a multiperson team in the introductory program. 


\section{Reflections on the Program}

In 2003, I invited Janet Lawrence, a faculty member in our Center for the Study of Higher and Post-Secondary Education (University of Michigan, $2007 \mathrm{~b}$ ), to carry out a review of our program. We had three overriding questions: (1) Was there evidence that graduate students participating in our program were becoming better educated about concerns and issues related to education? (2) Was there evidence that graduate students participating in our program were more aware of concerns and issues related to faculty careers? and (3) Was there evidence that the department had embraced this program as a core part of its mission? The results were all positive. It is unusual for a large research department to bring education on teaching and learning into its central mission, and one of the common questions we got early on was, "I can see how this might be accepted once it is established, but how did it get there?" William Roush, the department chair at the time, gave perhaps the best answer: "six hundred thousand dollars in graduate fellowships per year and a competitive advantage for recruiting graduate students and new faculty members creates lots of agnostics. ... They might not be believers, but they are not willing to get out the torches and pitchforks either ...."

There is a lesson here worth reflecting on about change. As a strategy, providing resources that attract faculty participation, in their familiar role as faculty advisors, appears to be much more effective than scolding them because of what they are not doing as well as you think they might.

My colleagues and I are certainly not alone in these efforts, although we think our plan is both philosophically and qualitatively different from other approaches. There is work across the country that can be interpreted as using one or more of the four characteristics of scholarship to engage students and faculty in teaching and learning. Undergraduate peer-led instructional programs speak directly to student engagement (Varma-Nelson and Coppola, 2005). At the graduate level, there are a large number of Preparing Future Faculty (PFF) programs (Preparing Future Faculty, 2007). Chemistry and physics departments that offer Ph.D.s in chemistry or physics education are carrying out informed and credible research (Coppola and Jacobs, 2002).

The PFF Program, in great part, was a response to the reports and concerns of young faculty and graduate students (Caserio and others, 2004; Golde and Dore, 2004) on whom expectations were rising but for whom there were diminishing resources. One of the important rationales for PFF programs was the fact that only 6 percent of schools grant doctoral degrees, so, by definition, the sort of school where a Ph.D. is likely to get an academic position is unlike the place where the doctorate was earned. In general, PFF programs expose students to the significantly different settings and concerns where the majority of higher education takes place. Although there is no single response to PFF programs, a caricature of the first reactions heard from the established STEM faculty is: "I did not need this, and I am a good teacher, why should they?" or "Nothing's broken. What are you 
trying to fix?" or "There is plenty done for young faculty once they start their careers." You get the idea.

PFF programs have raised the level of consciousness about improving professional readiness. However, with some exceptions, PFF is a marginalized activity and tends to be centralized administratively rather than in departments. There are too many stories of students in PFF programs who keep their participation below the radar for fear of retaliation from their advisors for being away from their research. The PFF curriculum is generally divided between administrative units (such as a graduate school) and the non-Ph.D.-granting partner schools; so, and I am critical here, mainstream faculty members have outsourced the "learning about teaching" part of their responsibilities. Perhaps not surprisingly, the national review (Boylan, 2003) found that PFF had had only moderate impact on change in either the core Ph.D.-granting departments and, interestingly enough, even less on the partnering departments.

\section{Reflections on Current Practices}

Over the years, I have worked with many of the people and organizations that have been concerned with improving higher education. These interactions have helped shape my thinking. Far from a critique, I want to provide brief reflections on the five efforts that, in my view, comprise the main landscape for thinking about teaching and learning in the United States. And as with all general characterizations, there are better and worse examples than the caricature, but I am attempting here to capture a general impression. Of course, these are my own impressions as someone looking into these initiatives. The leaders of these programs and efforts might describe them differently.

Professional and Organizational Development. The typical place where you find professional and organizational development (POD) activity is in a campus's center for teaching excellence or whatever it is called locally (POD Network, 2007). These organizations recognize that faculty members hit the ground of their new positions underprepared, and the staff of these centers provide much-needed intervention and service. While POD staff recognize that faculty members are the incomplete product of a flawed system, there is a tendency, in my view, to treat faculty members as students. And by treating faculty members as students and waiting until the start of one's professional appointment, the POD approach may inadvertently advance the "I have a teaching problem" mentality and does not address solutions for the flaws in the system that gave rise to the need for teaching centers in the first place. Finding ways for faculty members to take on responsibilities that are more like their work as research advisors taps into a quite different mind-set for thinking about education.

Scholarship of Teaching and Learning Community. The scholarship of teaching and learning (SoTL) initiatives has inspired mainstream 
faculty members to think about reflective practice and to treat one's individual activity in the classroom as an object of inquiry (Indiana University, 2007). And yet the SoTL community has wrestled with its relationship to the education research community since the outset. In the first issue of the International Journal on the Scholarship of Teaching and Learning (Georgia Southern University, 2007), the opening essay by Pat Hutchings focuses on the growth of using educational theory (and other theories) as a basis for carrying out classroom research. Nearly all of the articles in this issue, gathered in a section titled "Research," are indistinguishable from the papers one might find in education research journals. Does the scholarship of teaching and learning reduce to the subset of educational research when your own class is the object of the research? What is missing from these articles is any sense of faculty members who are teaching their subject and making teaching choices informed by work that aligns their instructional goals and methods. The scholarship of teaching and learning is too often used only as a noun; as a thing that is being done rather than an overall process.

The Ph.D. in the Disciplinary Education Community. This group fills a significant void in many schools of education where there is no research focus on postsecondary teaching and learning. In my discipline, and I know it is true for others, there is an unfortunate tendency for this group of faculty to see themselves as the self-appointed "chemical educators," and an even more unfortunate tendency for the rest of the faculty to think that this is just fine (Coppola and Jacobs, 2002). Two-tier faculty systems are intrinsically problematic. More than that, I cannot support a system that dissociates and absolves people who are called professors from their responsibilities as educators. Advancing the profession derives from individuals who possess a deeply integrated understanding of the subject and its pedagogy (Shulman, 1986; Magnusson, Krajcik, and Borko, 1999).

The Teaching-as-Research Community. This group recognizes the need to engage graduate students and faculty members together on projects that use research-based skills to examine and improve teaching and learning (University of Wisconsin, 2007a). As such, it shares many attributes with the SoTL community. The program has assembled extensive bibliographies on topics such as using diversity to enhance learning. The bulk of the investment is in workshops and classes at member institutions and now across the network of member universities. As with PFF and SoTL, the open concern is the degree to which large numbers of STEM faculty are deeply involved in the work and the extent to which graduate students' interest in developing as teachers is supported or marginalized by their faculty advisors.

The Adapt-and-Adopt Community. "Adapt and adopt" is a term used by the National Science Foundation (NSF) for its dissemination practices. NSF encourages the development of teaching materials that are relatively "teacher proof," or, in their lingo, "robust deliverables." I think robust 
deliverables are good-but also not so good. An important community of people has worked hard to make active classroom practices, as an example, accessible to faculty members who were otherwise treating classrooms as a place to deliver seminars. Personal responses systems, peer-led team learning (City College of New York, 2007), process-oriented guided inquiry learning (POGIL, 2007), and so on, many of which are the stepchildren of Angelo and Cross's classroom assessment techniques (1993) have actually changed practices. This is terrific. Unfortunately, from my point of view, there can be a methodological evangelism that does not care to link, or align, specific learning goals with a rationale for why understanding the subject matter will improve when these methods are used. That is, with this strategy, I have observed well-intentioned faculty who think about education as a trip to the supermarket to see what new products there are to pull from the shelf.

\section{Conclusion}

Improving and enhancing higher education is an irresistible force because it is, in the end, our job. And yet when this force hits the immovable objects of the twenty-four-hour day and conflicting work priorities, education efforts have generally ended up splintering ... . Cuban (1999) would say they were trumped . . . by incrementally growing demands to maintain research competitiveness. My view, which I have outlined in this chapter, is that we can do both by changing the way we do our work. In order to take on substantive research, STEM faculty learned that the twenty-fourhour-day barrier could be overcome by becoming more efficient. Research groups accomplish the twin goals of being able to organize a significant research effort while we ensure that the next generation of researchers inherits what we know and does not end up needing to reinvent those things. The features of that system are missing from teaching and learning, where faculty members inherit literally nothing about what is known and, as Cuban (1990) also rightly points out, end up "reforming . . . again, again and again" (p. 3). Cuban concludes that "waves [of reform] occur on the surface [of formal education] and, in some instances, programs, like the skeletons of long-dead sea animals, get deposited on the coral reef of schooling ... [yet reform itself goes critically unexamined]... . I end with a plea for rationality. . . If we do not heed the plea, we will continue to mindlessly speculate, and as Gide observed: Everything has been said before, but since nobody listens, we have to keep going back and begin again" (p. 12). I agree.

\section{References}

Angelo, T., and Cross, K. P. Classroom Assessment Techniques. San Francisco: JosseyBass, 1993. 
Bass, R. "The Scholarship of Teaching: What's the Problem?" Inventio, 1999, 1(1). Retrieved Mar. 23, 2007, from http://www.doit.gmu.edu/inventio/issues/Spring_1999/ Bass_1.html.

Boyer, E. L. Scholarship Reconsidered: Priorities of the Professoriate. Princeton, N.J.: Carnegie Foundation for the Advancement of Teaching, 1990.

Boylan, M. "Evaluation of the PFF Program." CIRTL Annual Forum, Madison, Wis., Nov. 2003. Retrieved Mar. 23, 2007, from http://cirtl.wceruw.org/Forum2003/ speaker_presentations.html.

Caserio, M., and others. "Responses to Changing Needs in U.S. Doctoral Education." Journal of Chemical Education, 2004, 81, 1698-1705.

Coppola, B. P. "The Most Beautiful Theories." Journal of Chemical Education, 2007, 84, $1902-1911$.

Coppola, B. P., and Jacobs, D. "Is the Scholarship of Teaching and Learning New to Chemistry?" In M. T. Huber and S. Morreale (eds.), Disciplinary Styles in the Scholarship of Teaching and Learning: A Conversation. Washington, D.C.: American Association of Higher Education and Carnegie Foundation for the Advancement of Teaching, 2002.

Coppola, B. P., and Roush, W. R. "Broadening the Existing Intergenerational Structure of Scholarly Development in Chemistry." Peer Review, 2004, 6(3), 19-21.

Cuban, L. "Reforming Again, Again, and Again." Educational Researcher, 1990, 19, 3-13.

Cuban, L. How Scholars Trumped Teachers: Change Without Reform in University Curriculum, Teaching, and Research, 1890-1990. New York: Teachers College Press, 1999.

Dawkins, R. The Selfish Gene. (New ed.) New York: Oxford University Press, 1989.

Georgia Southern University. "Theory: The Elephant in the Scholarship of Teaching and Learning Room." Jan. 2007. Retrieved Mar. 23, 2007, from http://www.georgia southern.edu/ijsotl/.

Glassick, C. E., Huber, M. T., and Maeroff, G. I. Scholarship Assessed: Evaluation of the Professoriate. San Francisco: Jossey-Bass, 1997.

Golde, C. M., and Dore, T. M. "The Survey of Doctoral Education and Career Preparation: The Importance of Disciplinary Contexts." In D. H. Wulff, A. E. Austin, and Associates (eds.), Path to the Professoriate: Strategies for Enriching the Preparation of Future Faculty. San Francisco: Jossey-Bass, 2004.

Goodwin, C. "Seeing in Depth." Social Studies of Science, 1995, 25, 237-274.

Gottfried, A. C., and others. "Design and Implementation of a Studio-Based General Chemistry Course at the University of Michigan." Journal of Chemical Education, 2007, 84, 265-270.

Hayward, L. M., and Coppola, B. P. "Teaching and Technology: Making the Invisible Explicit and Progressive Through Reflection." Journal of Physical Therapy Education, 2005, 19(3), 30-40.

Huber, M. T. Balancing Acts: The Scholarship of Teaching and Learning in Academic Careers. Washington, D.C.: American Association for Higher Education and Carnegie Foundation for the Advancement of Teaching, 2004.

Latour, B. Science in Action. Cambridge, Mass.: Harvard University Press, 1987.

Latour, B., and Woolgar, S. Laboratory Life: The Construction of Scientific Facts. Princeton, N.J.: Princeton University Press, 1991.

Lave, J., and Wenger, E. Situated Learning: Legitimate Peripheral Participation. Cambridge: Cambridge University Press, 1991.

Magnusson, S., Krajcik, J., and Borko, H. "Nature, Sources, and Development of Pedagogical Content Knowledge for Science Teaching." In J. Gess-Newsome and N. Lederman (eds.), Examining Pedagogical Content Knowledge: The Construct and Its Implications for Science Education. Norwell, Mass.: Kluwer, 1999.

Newstetter, W. "Designing Cognitive Apprenticeships in Biomedical Engineering." Journal of Engineering Education, 2005, 94(2), 207-213.

Shulman, L. S. "Those Who Understand: Knowledge Growth in Teaching." Educational Researcher, 1986, 15(2), 4-14. 
University of Michigan. "Genre Evolution Project.” 2007a. Retrieved Mar. 23, 2007, from http://www.umich.edu/ genreevo/.

University of Michigan. Unpublished document. 2007b. Retrieved Mar. 23, 2007, from http://www.soe.umich.edu/cshpe/.

Varma-Nelson, P., and Coppola, B. P. "Team Learning." In N. Pienta, M. M. Cooper, and T. Greenbowe (eds.), Chemist's Guide to Effective Teaching. Upper Saddle River, N.J.: Pearson, 2005.

BRIAN P. COPPOLA is Arthur F. Thurnau Professor of Chemistry and associate chair for curriculum and faculty affairs in the Department of Chemistry at the University of Michigan, Ann Arbor. He is the codirector of the IDEA (Instructional Development and Educational Assessment) Institute. 